УДК 821.161 .2

Юрчук Олена,

доктор філологічних наук, доцент, завідувач кафедри українського літературознавства та компаративістики Житомирський державний університет імені Івана Франка

\title{
«ДЛЯ ТОГО, ЩОБ ДІСТАТИСЯ СВІТЛА, ПОТРІБНО ПРОЙТИ ТЕМРЯВУ». ПРИКМЕТИ АНТИУТОПІЇ У РОМАНІ ЯРОСЛАВА МЕЛЬНИКА «МАША, АБО ПОСТФАШИЗМ»
}

У статті зосереджено увагу на романі Ярослава Мельника «Маша, або Постфашизм», котрий має виразні прикмети антиутопії. Автор моделює державу в далекому майбутньому, що вирізняється неогуманізмом. На позір ідеальне суспільство виявляється тоталітарним сочіумом, у якому люди володіють людиноподібними істотами - сторами. Роман Ярослава Мельника, як $i$ більшість антиутопій, актуалізує питання про людську свободу й кастовий поділ. Своєрідність «Маші, або Постфашизму» в тому, щуо питання свободи й поділу вирішується не в межах бінарної опозиції «людина людина», а «людина - тварина». Конфлікт людини й держави зумовлює не страх людини перед системою чи відчуття своєї вторинності, радме втому від перенасичення в задоволенні власних потреб.

Ключові слова: утопія, антиутопія, передбачення, ідеальна держава, неогуманізм, свобода, ритуал, людина, тварина.

В статье сосредоточено внимание на романе Ярослава Мельника «Мама, или Постфашизм», который имеет отчетливые черты антиутопии. Автор моделирует государство в далеком будущем, отличающиеся неогуманизмом. На первый взгляд идеальное общество оказывается тоталитарным социумом, где люди обладают человекообразными существами - сторами. Роман Ярослава Мельника, как и большинство антиутопий, 
актуализирует вопрос о человеческой свободе и кастовом разделении. Особеность «Маши, или Постфашизма» в том, что вопрос свободы и разделения решается не в рамках бинарной оппозиции «человек - человек», а «человек - животное». Конфликт человека и государства обуславливает не страх человека перед системой или ощущение своей вторичности, скорее усталость от перенасыщения в удовлетворении собственных потребностей.

Ключевые слова: утопия, антиутопия, предсказание, идеальное государство, неогуманизм, свобода, ритуал, человек, животное.

"To reach the light one should go through the darkness". The signs of anti-utopia in the novel "Masha, or the Fourth Reich» by Yaroslav Melnyk.

The article focuses on the novel by Yaroslav Melnyk "Masha, or the Fourth Reich», which has distinct signs of anti-utopia. The author simulates the state in the distant future, which is distinguished by neo-humanism and at the first look perfect society turns out to be a totalitarian society, in which people possess humanoid creatures - stors. The novel by Yaroslav Melnyk like most anti-utopias raises the question of human freedom and caste division. The peculiarity of "Masha, or the Fourth Reich» is the question of freedom and division, which is not solved within the binary opposition «man - man», but «man is an animal». The conflict between man and the state does not motivate a man's fear of a system or a sense of his secondaryness, rather a fatigue from over-saturation in meeting his own needs.

In most dystopia society demonstrates its own rigid structuring and baseness on a number of taboos that form the world of ordinary citizen. In "Masha, or the Fourth Reich» Yaroslav Melnyk models the world, which is in its very essence. Although the New Reich holds the highest Council of Cottres, however, the social life is carried out in accordance with the Constitution, in which the main paragraph is about human freedom. It would seem that such a society has nothing to do with the totalitarian. But the "game of democracy" ends where there is a threat of destruction of the system. Under such conditions the paragraph on human freedom ceases to be decisive. Instead of the prevailing paragraph is the protection of society, even by violating the rights and freedoms of its citizens.

In the novel «Masha, or the Fourth Reich» the world is ritualized. The author states the fact that any ritual that exists in society is sanctified by "history", that is its time repetition provides a sense of tradition. The plot conflict is connected with the reluctance to perform one or another ritual that is an inherent social role of the hero. A peculiar place in the dilemma between apparent well-being and inner loneliness is a human like an animal-Masha-stor. Initially, the protagonist's relationship does not go beyond his perceptible attitude to animals or stors. But the more he is aware of Masha's human nature the deeper the gap between them and the family.

An indication of a dystopia is the formation of a space of no alternatives, when every citizen of society is convinced that the system offered to him is the only correct and only possible one. The heroes of the novel "Masha, or the Fourth Reich» also believe that after World War II only their world survived that they are the only people on the planet Earth. A terrible shock for Dima's correspondent is the understanding that the Reich is "not a planetary state», that is a world where only humans live and there are no stors where even time is excellent.

So, the author solves the myth about the possibility of creating an ideal society. The new humanism of the Reich, after which people possess human beings - the seams, leads to the spiritual degradation of a person who is in a «social lethargic dream» of security. animal.

Key words: utopia, dystopia, anticipation, ideal state, neo-humanism, freedom, ritual, man,

Рефлексуючи над історією української літератури на рівні жанрової парадигми, очевидним стає той факт, що деякі жанри, апробовані в світовому мистецтві слова, все так само залишаються маргінальними для національного 
літературного та літературознавчого дискурсів. Так помітним було недостатнє зацікавлення жанром антиутопії. Віднедавна ситуація дещо змінилася. Наразі спостерігається пожвавлення інтересу до антиутопії. Українські видавництва не тільки публікують класиків цього жанру в українському перекладі (тексти Олдоса Гакслі, Джорджа Орвелла, Рея Бредбері, Вільяма Голдинга), а й видають сучасних українських авторів. Чільне місце серед них належить антиутопіям «Червона зона» Артема Чапая, «Кагарлик» Олега Шинкаренка, дистопії «Помирана» Тараса Антиповича.

У пропонованому дослідженні зосередимо увагу на романі Ярослава Мельника «Маша, або Постфашизм», котрий має виразні ознаки антиутопії. Творчість митця вже неодноразово втрапляла в коло зацікавлень. У передмові до роману «Далекий простір» Марія Матіос зазначала, що проза Ярослава Мельника «...не по-українськи стримана, по-чоловічому небагатослівна, 3 незвичною для мене енергетикою, незвичними фантасмагоріями, наукоподібною містикою» [Матіос 2013 : 6].

Дмитро Дроздовський «Машу, або Постфашизм» називає черговою постніцшеанською історією «...про те, як людина убила Бога i зробилася Богом» [Дроздовський 2016]. Віра Агеєва у рецензії на роман вказує, що «антиутопія Ярослава Мельника спершу затягує неймовірно захопливим сюжетом, a потому змушує задуматися над речами, які здаються самоочевидними, - але враз висвітлюються нестерпно яскравим променем, постаючи або потворно деформованими, або незвично, неприкрашено реальними. Між настановою на деформацію і прагненням реалізму в цьому тексті важко знайти межу» [Агеєва 2016]. Ганна Улюра розглядає цей же текст у контексті трешу: «Те, що для Люби Клименко - конкурентна гра на полі культурного виробництва, для Ярослава Мельника - боротьба за канон. Та все ще йдеться про треш: щодо нього культова цінність і повноцінна художня цінність - це суто і виключно опозиції» [Улюра 2016 : 119].

Та повернімося до рис антиутопії у романі «Маша, або Постфашизм». Найперше - автор створює модель майбутнього суспільства, важливою 
ознакою якого $є$ неогуманізм. Ярослав Мельник уникає хронотопної невизначеності, що найчастіше слугує універсалізму в антиутопіях, пропонуючи конкретизований час - XXXIX століття та місце - третя зона четвертого сектора Свразійського штату рейха. Отже, перед читачем текст, побудований за принципом альтернативної історії, коли засадничим $\epsilon$ припущення «що було б, якби». Ярослав Мельник пропонує уявити суспільство, що виникло як наслідок перемоги фашизму під час Другої світової війни. Зауважимо - це поширений сюжет. До прикладу, альтернативний роман Філіпа К. Діка «Людина у високому замку», в українській літературі «Дефіляда в Москві» Василя Кожелянки.

Змодельований автором у «Маші, або Постфашизм» герметичний світ на позір видається ідеальним суспільством, в якому панує мир, відсутня злочинність і технологічний розвиток - люди живуть у світі, який забезпечує їх вітальні потреби. Ілюстрацією такого життя стає сім’я кореспондента газети «Голос Рейха» Діми, котрий володіє заміським будинком i фермою, має родину - дружина Ельза й син Альберт. Але знайомимся ми з головним героєм поза межами його зони комфорту - на м’ясокомбінаті, що вже має викликати неприємні емоції, адже це місце, де здійснюється вбивство тварин. Автор розлого описує комбінат, зосереджуючи особливу увагу на процесі вбивства й наступної обробки м’яса: «Тварину, прив’язану до стійки, доправляла до забійної одна зі стрічок конвеєрів. Екзекутор приставляв до вуха тварини електричний щуп і натискав пальцем на кнопку. Лунав крик - i тварина падала на стрічку вже мертвою. За якусь хвилину іiі розділяли в обробному цеху, сортуючи частини тіла. Найсмачніші місця прямували відразу до пакувальної, де, опущені у спеціальні пакети, були готові потрапити відразу до крамниць» [Мельник 2016 : 14].

I все б нічого (за умови, якщо не належиш до вегетаріанців), якби у голові нашого героя не зринали думки про зовнішню схожість між тваринами й людьми. Це наштовхує на здогад, що перед нами не ідеальний світ, де панує новий гуманізм, а гибле місце або псевдогуманістична цивілізація, в якій люди 
володіють людьми, вдаючись до підміни понять: «Якщо це «копито» назвати «ступня» (та сама зовнішня схожість із людською кінцівкою), то відбудеться руйнування світу. Вийде, що людина їсть людину» [Мельник 2016 : 15].

Варто наголосити на амбівалентній природі думок головного героя: 3 одного боку, він дозволяє собі міркування про схожість природи людини й людиноподібної тварини - стора, з іншого - намагається блокувати їх догмами нового гуманізму, що його підтримує система Рейха. Ярослав Мельник підкреслює амбівалентність мислення громадянина нового світу описом поїдання пиріжка «Сюрприз», в якому запечене невелике серце (ймовірно, дитяче): «Я замовив гарячий пиріжок «Сюрприз» i склянку бульйону. У пиріжку було запечене невелике серце. Смакота» [Мельник 2016 : 15].

Отже, перед нами ідеальний світ у далекому майбутньому, в якому гармонія і новий гуманізм досягаються у феноменальний спосіб - люди називають інших людей сторами й тим самим нівелюють їх людську природу. Життєустрій Рейха раціональний i алгоритмізований. Роман містить низку аргументованих вкраплень публіцистичного характеру, що дозволяють прослідкувати інволюцію людини в стора. Джон Шевчук, доктор філософії й Головний Радник Контрольної Ради Рейха, міркуючи про фашизм, подвійну мораль колишніх цивілізацій, знаходить відповіді або виправдання нового гуманізму Рейха. Він визнає фашизм як нелюдське явище, однак, єдиною провиною останнього є неспроможність переконати «себе й інших», що в концтаборах перебувають «...не люди, “нижча раса”, щось на зразок тварин...» [Мельник 2016 : 24]. Пан Шевчук вважає, що фашизм лежить біля витоків сучасної йому цивілізації, адже вперше озвучив ідею, що «...не кожне анатомічно «людське» тіло належить людині» [Мельник 2016 : 24]. Зазначена ідея згодом стала приводом до людської селекції, наслідком якої і є розрізнення людей і сторів.

Ярослав Мельник у романі не оминає традиційного для антиутопії питання про людську свободу й кастовий поділ. Своєрідність «Маші, або Постфашизму» в тому, що воно озвучується в межах бінарної опозиції 
«людина - тварина». Страх людини перед системою чи відчуття своєї вторинності нівелюється, натомість домінує втома від перенасичення в задоволенні власних потреб, коли ситість провокує вихолощення почуттів та емоцій - емпатичний атавізм. Саме це стимулює до вирішення проблеми й зумовлює цікавість людини «Іншим світом» та «Іншими», що одночасно схожі й відмінні від неї, а як наслідок з'являється апорія щодо сутності стора. Чи й справді стор - це не людина? Чи можливо це все ж людина? Отож, люди не тільки експлуатують, а й їдять людей. Вона ускладнена засвоєною ідеологією, за якою живе більшість громадян Рейха. Пізнаючи світ сторів, головний герой не може позбутися відчуття збоченості у власних думках і діях, адже любити людину - це гуманізм, а любити стора - це скотолозтво: «Чорт забирай, я торопів! Перед твариною. Почувався маленьким, мало не в їі владі. Я побачив у ii очах бажання і не на жарт перелякався. Окремі випадки зоофілії мені були відомі, але потрібно було поставити на собі хрест як на людині, погодившись на інтимний зв’язок з твариною» [Мельник 2016 : 37].

Прикметно, що в центрі антиутопії обов’язково перебуває проблема Добра й Зла, але в романі Ярослава Мельника вона виходить за межі звичного розуміння. Знущатися над людиною, піддавати iї тортурам, їсти - це безперечно Зло. Вчиняти всі ці самі дії щодо тварини - теж Зло. Але, якщо в такий спосіб людина сублімує своє бажання до насильства, тоді історія знущань над сторами - це лише невелике Зло в межах великого Добра незнущання над людиною.

У більшості антиутопій суспільство чітко структуроване й підпорядковане певним табу, що формують світ пересічного громадянина. Так, у романі Джорджа Орвелла «1984» вже 3 першої сторінки дізнаємося, що герой Вінстон Сміт живе у світі, де «старший брат пильнує за тобою». Рей Бредбері повість « $451^{\circ}$ за Фаренгейтом» починає 3 епізоду спалення будинку, в якому читають книжки, бо читати протизаконно. У «Маші, або Постфашизм» Ярослав Мельник моделює світ, який відмінний за своєю суттю. Новий Рейх хоч і має Вищу Контрольну Раду, однак його суспільний життєустрій здійснюється 
відповідно до Конституції, в якій базовим є параграф про людську свободу, що не має нічого спільного 3 тоталітарним устроєм. Але «гра в демократію» закінчується там, де виникає загроза існування системи. За таких умов параграф про свободу людину припиняє бути визначальним. Натомість превалюючим стає параграф про захист суспільства навіть шляхом порушення прав і свобод його громадян: «Конституція (навіть найбільш вільна) чимось може існувати лише після того, як забезпечено існування цього “чогось". Як сказано в Постанові Вищої Контрольної Ради: відтепер, з метою збереження стабільності на планеті Земля, забороняється пропаганда будь-яких ідей, що виходять із так званого “вчення консервативного гуманізму”. Особи, які поширюють ці шкідливі і надзвичайно небезпечні ідеї, будуть відтепер затримані та ізольовані» [Мельник 2016 : 159].

Світ у романі «Маша, або Постфашизм» ритуалізований. Автор констатує факт, що будь-який ритуал, котрий існує у суспільстві, освячений «історією», тобто його часова повторювальність забезпечує відчуття традиції. Цей механізм спрацьовує навіть із тими ритуалами, що ймовірно мали б відштовхнути людину, свідомість якої вже не знаходиться на первісній фазі, а ускладнена догмами моралі, в якій пріоритетним є імператив - «не вбий». Однак, Дубов у розмові з Дімою безапеляційно стверджує: «Страшно і неприйнятно лише те, що ти робиш сам по собі, вперше. Але варто цьому перейти в традицію - як воно освячується і стає звичайним. “Не могли ж діди-прадіди помилятися!” “Не могли ж вони бути людоїдами!”» [Мельник 2016 : 146].

Сюжетний конфлікт пов'язаний із небажанням виконувати той чи інший ритуал, що іманентний соціальній ролі героя. Кореспондент Діма відчуває відчуження у власній родині: «Дружина та син були єдиними у світі людьми, поруч 3 якими я не хотів жити, настільки я відчував себе непотрібним, зайвим» [Мельник 2016 : 75]. Мова не йде про відкритий конфлікт, що міг завершитися емоційним катарсисом, а про відчуття витісненого невдоволення.

Особливе місце у дилемі між позірним добробутом i внутрішньою самотністю займає людиноподібна тварина - стор Маша. Спочатку стосунки 
героя і стора не виходять за межі зрозумілого Дімі ставлення до тварин. Усі загальновідомі інтенції про те, що чим більше людина пізнає людину, тим більше вона захоплюється тваринами, стають для героя реальністю. Якщо відкинути людську природу стора й мислити про нього в «тваринній системі координат», то виникає відчуття, що автор проектує уявну спільноту, яку наділяє особливістю, що незабаром може стати реальністю нашого суспільства, - люди для спілкування обиратимуть тварин (у тому й феномен передбачення, що закладено в антиутопії). Але чим більше герой усвідомлює людську природу Маші, тим глибшає прірва між ним й родиною: «Ельза, син вони були поруч, але ... не відображали мене. Тобто вони мене відображали, але так, що я дедалі частіше жахався. Я не був собою з ними. Це були не ті люди, які могли б зрозуміти мене в потаємному - зрозуміти i, можливо, пояснити мені себе самого» [Мельник 2016 : 94].

Поштовхом для відмови від загальновизнаного способу життя для Дмитра стають дві, з одного боку, відмінні, з іншого - досить схожі історії. Найперше, це історія спарювання Маші як невеличка подорож, у якій головний герой переживає спектр різних почуттів: від сексуального потягу до невмотивованої агресії. Друга історія також пов’язана зі стором - історія вбивства Рудої, яка видається сексуально привабливим об’єктом, але агресія щодо якої цілком виправдана («Руда кричала вже не своїм голосом - від жаху, від страху смерті. Кричала глухо, з-під Розенберга. Обличчя іï я не бачив - тільки правильної форми тіло, з красивими стегнами, зі симетричним розплесканими півмісяцями сідниць, що виглядали з-за стегон, із дивовижно збереженою, як для іiі віку, талією» [Мельник 2016 : 50]). В обох випадках головний герой відчуває тотальне розчарування й відразу, що в свою чергу стає стимулом до прозріння стори таки люди: «І тут я виразно зрозумів, що переді мною стоїть людина. Справжнісінька людина, тільки гола i побита мною» [Мельник 2016 : 66]. Звичний світ, у якому герой виконує ритуали, що вирізняють його роль власника ферми: сприяння процедурі спарювання тварин, доїння молока в самиць, «коління» їх задля вживання у їжу, руйнується. Відмовляючись від 
винагороди - м’яса вбитої ним Рудої, Діма порушує протокол ритуалу й ставить його під сумнів. Хоч саме він долучає героя до родинної традиції, за якою чоловіки роду виконували функцію «колюнів».

Діма усвідомлює хибність власного способу життя, однак це не спонукає його до активних дій. Ймовірно, герой все так само продовжував би перебувати в полоні внутрішньої дилеми, не зважуючись щось змінити, якби не заздрість до колеги Дубова. Ярослав Мельник вдається до викриття людської природи: не усвідомлення власної жорстокості щодо інших може штовхнути людину до змін, а заздрість до тих, хто на них спромігся: «Раптом я позаздрив: йому є чим жити. Він живе. Він радий, що головного зняли, що нарешті “щось сталося”. Що можна “протестувати”, “боротись за щось”. Не важливо за що - тільки би не ці вбивчі будні газети, яка “висвітлює наше мирне життя”. Хотів би я так бачити сенс у звільнення з газети, як він» [Мельник 2016 : 95].

Прикметою антиутопії є формування простору безальтернативності, коли кожен громадянин суспільства впевнений, що пропонована йому система не має інших варіантів існування. Герої роману «Маша, або Постфашизм» також вірять, що після Другої світової війни вцілів лише їх світ, а вони є єдиними людьми на планеті. Страшним потрясінням для кореспондента Діми стає усвідомлення, що Рейх - «не планетарна держава», що є світ, де живуть тільки люди і немає сторів, де навіть час відмінний: «Вони живуть у тому ж часі, що й ми, тільки у них інше літочислення. I все життя - інше» [Мельник 2016 : 265].

Роман Ярослава Мельника «Маша, або Постфашизм» містить у собі структурні ознаки антиутопії, однак виникає певна складність із остаточним розумінням його природи як суто антиутопічної. Видається, що перед нами твір, у якому превалююча антиутопічна інтенція поєднується з гуманістичною вірою автора в неймовірну силу людського кохання, що в свою чергу наближає читача до утопічної ілюзії про можливість перемогти систему, щоб потім взятися за руки й на сідницях з’їхати у долину - новий світ: «Він ще щось говорив, але я вже не слухав. Я взяв Машу за руку, і ми, посміхнувшись одне одному, перші - з’їджаючи на сідницях - почали спускатися у долину» 
[Мельник 2016 : 278]. Такий щасливий кінець чомусь викликає сумнів. Ярослав Мельник на початку книги подає декілька провокативних епіграфів, що у певний спосіб $є$ антагоністичними. Кільцевим обрамленням для епіграфів слугують цитати з текстів Фрідріха Ніцше. Тому насамкінець також вдамося до ілюстрації власного сумніву словами німецького мислителя. У книзі «Людське, занадто людське» він констатує: «Той, хто ухиляється від звичного, стає жертвою незвичного, хто залишається у звичному, той стає його рабом. У тому й іншому випадку людина гине» [Ніцше 2007 : 342].

Отже, у романі Ярослава Мельника домінантними є прикмети антиутопії. Автор розвінчує міф про можливість створення ідеального суспільства. Новий гуманізм Рейха, за яким люди володіють людиподібними істотами - сторами, призводить до духовної деградації особи, що перебуває у «соціальному летаргічному сні» забезпеченості. Долаючи запрограмованість власного життя, головний герой Діма входить у конфлікт із собою, що в свою чергу стає основою для конфлікту 3 державою. Ймовірно, він не до кінця усвідомлює соціальний абсурд системи, в яку інкорпорований, але прагне розпочати «справжнє життя, а не животіння».

\section{БІБЛІОГРАФІЯ}

Агеєва 2016 - Агеєва В. Всепереможність краси, або Про кохання і канібалізм [Електронний ресурс] / Віра Агеєва. - Режим доступу : http://starylev.com.ua/club/article/vseperemozhnist-krasy-abo-pro-kohannya-ikanibalizm

Дроздовський 2018 - Дроздовський Д. Як не стати на бік Зла: версія Ярослава Мельника [Електронний ресурс] / Дмитро Дроздовський. - Режим доступу : https://day.kyiv.ua/.../yak-ne-staty-na-bik-zla-versiya-yarosla...

Матіос 2013 - Матіос М. Свобода українського литовця Ярослава Мельника // Мельник Я. Далекий простір / Ярослав Мельник. - Харків : Книжковий Клуб «Клуб Сімейного Дозвілля», 2013. - С. 5-6. 
Мельник 2016 - Мельник Я. Маша, або Постфашизм : роман / Ярослав Мельник. - Львів : Видавництво Старого Лева, 2016. - 288 с.

Ницше 2007 - Ницше Ф. Человеческое, слишком человеческое : Книга для свободных умов / Ф. Ницше. - СПб. : Издательский Дом «Азбукаклассика», 2007. - 384 с.

Улюра 2016 - Улюра Г. Живе тіло, мертве тіло і напівживе: культурне заміщення і конструювання гендеру / Г. А. Улюра // Новітні праці. Філологія. Літературознавство. - 2016. - Випуск 259. Том 271. - С. 116-121. 